\title{
Gnawing Away at the City: Narratives of Domestic Precarity in a Congolese Mining Town
}

\author{
Kristien Geenen (1)
}

\begin{abstract}
The relationship between urbanization and mining is a precarious one; the latter often expands at the expense of the former. The incautious urban planning of a mining city in southeastern DR Congo, however, has opened up opportunities for residents with artisanal mining skills. Since the city is constructed on top of mineral deposits, the residents are able to dig ore in their own backyards to draw their subsistence. Based upon archival and ethnographic research, Geenen argues that, by self-generating the livelihoods they expected their resource-rich soil to bring forth, these artisanal diggers take advantage of the urbanized mineral deposits and write their own narrative of capitalism.
\end{abstract}

Résumé: La relation entre l'urbanisation et l'exploitation minière est précaire ; la seconde se développant souvent au détriment de la première. L'urbanisme imprudent d'une ville minière dans le sud-est de la RD Congo a cependant ouvert des possibilités pour les résidents ayant des compétences en matière d'exploitation minière artisanale. Comme la ville est construite sur des gisements minéraux, les habitants peuvent creuser le minéral directement dans leur propre jardin pour en tirer leur subsistance. Sur la base de recherches archivistique et ethnographique, Geenen soutient qu'en produisant eux-mêmes leurs moyens de subsistance attendu de leur sol riche en ressources, ces creuseurs artisanaux profitent des gisements de minéraux urbanisés écrivant ainsi leur propre récit du capitalisme.

African Studies Review, Volume 0, Number 0 (2020), pp. 1-22

Kristien Geenen (doctor in Social and Cultural Anthropology) has long-standing fieldwork experience in urban DR Congo, more particularly in the cities of Kinshasa, Butembo, and Kolwezi. She is currently affiliated with Université de Liège and has a keen interest in urban studies and historical research. E-mail: kgeenen@uliege.be

(c) The Author(s), 2020. Published by Cambridge University Press on behalf of the African Studies Association.

doi:10.1017/asr.2020.65 
Resumo: A relação entre a urbanização e a atividade mineira é de natureza precária: o desenvolvimento desta última faz-se muitas vezes à custa da primeira. Porém, o descuidado planeamento urbano de uma cidade mineira no sudeste da República Democrática do Congo abriu caminho a novas oportunidades para os moradores que detêm competências para a prática artesanal do garimpo. Porque a cidade foi construída diretamente sobre depósitos minerais, os moradores conseguem escavar a terra em busca de minérios nos seus próprios quintais, assim garantindo a subsistência. Partindo de um trabalho de investigação etnográfica e arquivística, Geenen sustenta que, ao gerarem os meios de subsistência que esperavam obter através da riqueza dos seus terrenos, estes garimpeiros artesanais tiram partido dos depósitos minerais urbanizados e escrevem a sua própria narrativa do capitalismo.

Keywords: DR Congo; mining cities; urban planning; artisanal mining

(Received 19 September 2018 - Revised 27 May 2020 - Accepted 29 May 2020)

In May of 2018, Gilbert, a resident of Kolwezi, was awakened from his slumber by a bouncing sensation and a loud banging. The noise, caused by another resident illicitly digging underneath the house of Gilbert's neighbor, so "alarmed the neighbors" that "they reported the digging to the authorities who immediately showed up to intervene." 1 The peculiar location of the Congolese city had triggered this nightly digging; Kolwezi is situated right on top of mineral deposits. While residents are routinely asked to relocate to allow mining companies to tap the deposits underneath their dwellings, the unusual location also allows citizens to profit from the precious ore in their own backyards. While the residents living in former labor camps in close vicinity to mines, such as Gilbert, have always known that it was forbidden to dig minerals in their compounds, those living in the newer neighborhoods have fewer qualms about doing so and en masse root their backyards out. This exposes inhabitants to a new danger: illegal artisanal mining beneath their very beds.

Gilbert's experience is hardly exceptional. Today, Kolwezi is a makeshift city, constructed hastily in the 1930s, without creating an urbanization plan or performing any soil testing. Worldwide, as cities grow, they are branded and become smarter. Public displays of urban development, however, often enlarge the chasm between rich and poor. The construction of mega-projects or the gentrification of neighborhoods often occurs at the expense of deprived residents who are forced to relocate in the face of rising rents. In the eyes of the needy, all this progress is so near and so visible and yet so hard to grasp. Such daunting urban inequalities challenge the disenfranchised, who look for ways to participate in urban buoyancy and improve the conditions of their everyday lives. Their individual practices convey personal approaches to the rearrangement of a city's fortunes as they seek to lay claim to the future. Urban residents inscribe themselves into a network of capitalist 
production, and in so doing link their local economic practices to global capitalist operations. They may not necessarily establish such connections fully cognizant of the stakes; rather, they seize emerging opportunities to secure their own livelihoods.

This article explores how ill-conceived urban planning in a mining town has been transformed into value by disenfranchised citizens eager to claim their share of the mining boom and to be incorporated into capitalist production. Kolwezi's location is unfortunate, insofar as it is situated directly atop valuable mineral deposits. The mining company Union Minière du Haut-Katanga, or UMHK (currently Gécamines), is the progenitor of Kolwezi, and the interests of this company fully determined its location. UMHK's insistence on building the city in a hurry has far-reaching consequences today. Only after the provisional buildings on haphazardly chosen plots gradually became permanent did it become apparent that the city-in-the-making was trapped, completely surrounded by industrial mining areas, which narrowed options for future expansion. Similar to the port city of Matadi (Lagae et al. 2016), where the peculiar topography of cliffs and slopes has curbed future expansion, Kolwezi appears to have been built in the wrong location.

However, the Kolwéziens make as much as they can of the situation by digging up mineral ore in their backyards and selling it to the local trading houses. At the end of the global chain, this cobalt ends up in devices such as mobile phones and electric bikes. Although conditions are harsh and unsafe, this salvage accumulation does allow a considerable number of city dwellers to make ends meet. As such, Kolwéziens find ways to self-generate the expected development due to the mineral-rich soil. They adjust to their peculiar urban and geological context and use it to sustain their personal advancement. Various scholars have discussed the self-reliance of the Congolese, their débrouillardise, their extraordinary capacity to turn unpromising situations into profitable ones (Ayimpam 2019; De Boeck \& Plissart 2004; Trefon 2004). The city dwellers of Kolwezi similarly make the most of their unfortunately located town by reaching out and connecting to the global economic networks that span their city. Their worlding is a means of responding with genuine inventiveness to the peculiar urban features of their city. Many Kolwéziens have the feeling that they have not fully profited from the mining boom that has engulfed their city since the coming of the major international companies from 2008 onward. Although their living standards are relatively higher compared to other areas of DRC, they want to find ways to get more involved, to acquire an income suitable for residents of a mining city.

This article explores the particular kind of "cityness" (Robinson 2002; Pieterse 2010) of Kolwezi, a place so rooted in the extractive industry that it conjures up “a science-fiction landscape” (Bruneau \& Mansila Fu-Kiau 1986). It is a place where mining continuously expects its inhabitants to (be prepared to) move. It is a city that conceivably may have to be removed and relocated in its entirety. But it is also a place where residents take advantage of this predicament, and through their salvage accumulation 
assure a connection to capitalist circuits. By self-generating the livelihoods they expected their mineral-rich soil to bring forth, Kolwezi's domestic diggers are able to write their own capitalist narrative.

My argument emerges from a close reading of the correspondence between representatives of UMHK and the Belgian colonial authorities at the African Archives in Brussels and from recent interviews with city dwellers, experts, and authorities in Kolwezi. The article is organized into two parts: the first is situated in the past, and the second in the present day. I first situate Gilbert's predicament vis-à-vis current debates about labor precarity. I then outline the historical context of the city's development, and illustrate that the logics of capital accumulation were decisive for the way it grew. I subsequently explore how the current inhabitants of Kolwezi deal with the result of the entanglement between the mining industry and urban planning. By way of a conclusion, I outline how residents find ways to incorporate capitalist circuits, although their understanding of these circuits is often incomplete.

\section{Resituating Precarity in African Minefields}

The unnamed miner beneath the home of Gilbert's neighbor is but one of many. For many participants in domestic and globalized economies, opportunities often emerge in the form of temporary jobs in precarious circumstances. Anna Tsing (2017 [2015]) explores how economically vulnerable groups succeed in connecting to the global supply chain, albeit in precarious and uncertain conditions. Via the matsutake, a sought-after delicacy in Japan, we learn how mushroom pickers in the U.S., Finland, and China exemplify general conditions of precarity. As she puts it, "Industrial work no longer charts the future. Livelihoods are various, cobbled together, and often temporary" (2017 [2015]:132). Tsing frames the temporal coordination of temporal earnings as "salvage accumulation." Such working conditions exemplify the current zeitgeist; they are not "bullshit jobs" (Graeber 2018), but rather, they exist in tandem with the way that market demands integrate into capitalist circuits.

Precarious and lacking long-term viability, salvage accumulation merely enables individuals to piece together a livelihood. In a not dissimilar way, African urban residents in search of better lives reach out to a broader world. They adapt their actions according to profitable homegrown strategies. To some, the worldwide web opens opportunities, such as financial gain through internet dating (Cassiman 2019) or permanent residency (Piot \& Batema 2019). Others establish global connections through associations within their city (Simone 2001). So-called "worlding" practices, processes of scaler recomposition that "conjure up worlds beyond current conditions of living" (Ong 2011:13), constitute, for AbdouMaliq Simone (2001:18) "a process inherent in the very formation of African cities themselves."

The confrontation with progress and wealth, and with what life could be, is particularly brutal in mining cities. Residents actually watch many ore 
trucks passing through, they see the tailings piling up, they see the productive shafts. They notice the money that employees of mining companies lavishly spend. Although nearby, this bounty remains out of reach to most residents. Whereas to some, the mining industry offers job opportunities and ensuing benefits, to others, it means a deterioration of basic urban infrastructure, for instance, when through the excessive use of electric power to feed the plants, ordinary inhabitants are sporadically cut off from the power grid. There is a general consensus in African urbanism literature that the defining feature of African urbanism is the precarity and provisionality of the built environment, and mining towns particularly exude this condition of temporariness, if not uncertainty. For one thing, they are put to the test by the expansion of mining activities, especially if it concerns open pit mines that, through their gradual expansion, literally devour the city (Finn 1998; Francaviglia 1991; Leech 2018).

Extraction develops in cycles. Mining investments fluctuate with the demand on the global market and the related price of the mineral ore, fluctuations which can result in the (temporary) withdrawal of mining investors and the suspension of mining activities. Mining towns abide by this rhythm of booms and busts, and populate and depopulate accordingly. This, in turn, occasionally leads to "shrinking cities" (Martinez-Fernandez \& Wu 2009; Martinez-Fernandez et al. 2012), or even to cities which simply cease to exist. Illustrating the temporary vicissitudes accompanying extraction, the mining towns that spontaneously appeared after artisanal miners started to dig in eastern DR Congo (Büscher 2018) or in the Lunda provinces in Angola (Udelsmann Rodrigues \& Tavares 2012) will likely disappear once deposits are exhausted. Consequently, the urban planning and development of mining towns has often occurred with a short-term, limited vision. The erratic relation between mining and urban planning has been explained as "mineralized urbanization" (Bryceson \& MacKinnon 2012), or "extractive pace" (Kesselring 2018) and "embodied extraction" (Vandemoortel 2014). The co-existence of multiple forms of capitalism and extractive practices characterize the African mining town, insofar as industrial and artisanal mining often operate side by side.

The particular geographical features of mining cities have repercussions on urban social tissue. Besides disrupting the urban landscape, the presence of the mining industry creates a sense of inequality among the residents. An assumed relationship between minerals and a capacity to bring about positive change was put to rest by James Ferguson (1999), who dimmed such "expectations of modernity." Mukohya Vwakyanakazi (1988) outlined how the omnipresence of fully self-supporting parastatals produced "stifling mechanisms" that deprived the rural areas of any chance to fully develop. Miles Larmer rejects a straightforward minerals-development relationship because areas develop "in uneven ways" (2016:9). Rather than tantalizing benefits and improved living standards, mineral richness renders for many a "permanent precarity" (Larmer 2017). Just as during colonial times, earnings were channeled "by economic policies... to the metropole exchequers and to Western- 
based companies" (Larmer 2017:9), this extraction continues today in the form of gargantuan multinationals. Ching Kwan Lee (2017) reveals how the Zambian copperbelt profits go almost exclusively to Lusaka, and miners continue to live in unfavorable conditions. And as Joe Trapido (2015) has outlined, financial means consistently flow out of Central Africa's "leaky giant," keeping the DR Congo as a whole, and the broad majority of its inhabitants specifically, from profiting to the fullest from the country's generously mineralized soil. The mining industry is not a life-changer for all.

\section{A hurried city: Kolwezi at the service of the mining industry}

A myriad of metals and minerals can be extracted from the ore in the area around Kolwezi, but cobalt and copper are the most prominent ones. After a period of prospecting that took off during the Congo Free State and continued under Belgian Congo, industrialization ensued. Initially, one single company-Union Minière du Haut-Katanga, or UMHK (currently Gécamines) - embodied the mining industry, and its interests solely determined the location of the city of Kolwezi. In this section, we will discuss UMHK's insistence on building the city in a hurry, setting up makeshift buildings even before the authorities developed an urbanization plan, a modus operandi that has far-reaching consequences today.

To state that mining is at the origin of cities throughout the Congolese Copperbelt is to belabor the obvious. But contrary to what is often assumed, colonial cities in Africa were hardly ever built up from scratch; they usually developed on sites of existing cities (Coquery-Vidrovitch 1988), or on places where human activity was concentrated well before the arrival of the colonizers. These places could be crossroads of trading routes, important marketplaces, or-as is the case in Kolwezi-mining sites. Indeed, the colonizing forces did not discover the deposits, but "prospecting in Katanga was reduced to locating 'ancient workings' rather than using scientific exploration methods to discover previously unknown ore bodies" (Särkkä 2016:330). ${ }^{2}$ On the site in the savannah where the future city of Kolwezi would develop, there were three deposits: Ruwe (then mainly gold), Musonoi, and Kolwezi (both copper). There were some villages, too. It was above all the Sanga ethnic group that was mining and smelting copper long before the European expeditions arrived (see Mukembe Mubedi 2018; Gobbers 2016; Cuvelier 2011; Van Doorninck 1928; De Hemptinne 1926). As such, rather than a creation of this city by colonial powers, it concerns a "fixation" of urban space (Gondola 1997:35) on sites that were previously buzzing with activity. ${ }^{3}$

In any case, when mining prospectors "discovered" these three rich deposits, they faced a major problem; the site was rather isolated, and options for export were few. An experiment in 1906 proved that it took an oxcart as long as eight months to transport the mineral ore and ingots from Ruwe to the Angolan port for shipping, hardly a viable production line. ${ }^{4}$ There was no sense in developing any industrial activity there, if profitmaking was beyond reach. Therefore, UMHK shifted its focus to its other two centers of activity, 
Figure 1. Map from 1930 showing how the railway linking the Angolan coast to the deposit of Ruwe is in the making. Source: AA 3DG(1988)2.

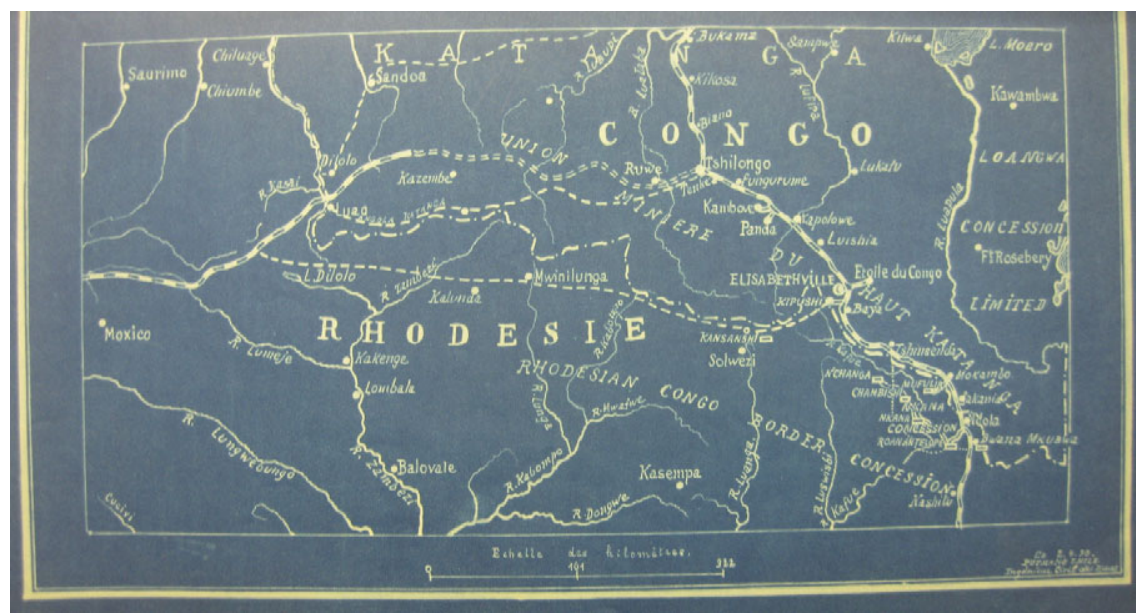

Elisabethville with the Etoile du Congo mine and Panda with the Kambove mine, as these two had been connected by railway to the Cape since 1910 (on the railway network, see Katzenellenbogen 1973; Hance \& van Dongen 1956) (see Figure 1).

However, when at the beginning of the 1920s it became clear that a railway connection to the future town of Kolwezi would be forthcoming at some point, UMHK resumed prospecting at so-called Groupe Ouest, particularly at the deposits of Ruwe and Musonoi..$^{5}$ These mining activities ushered in the era of urbanization. The first built areas consisted of the labor camps that UMHK constructed near the mines to accommodate its workforce. As Bruno De Meulder (1996) has shown, these camps combined temporariness with rationality. To ensure the availability of a sufficient number of competent and healthy workers, accommodating them next to their place of work seemed a foolproof solution. So UMHK built these labor camps as close as possible to mines and in non-durable material. A close look at the correspondence between the company and the colonial authorities clearly shows that they proceeded in a somewhat haphazard fashion, seemingly averse to basic urban planning principles. The provisional prevailed, and permanent solutions were postponed. For one thing, there was no master plan; proximity to a center of activity was the sole criterion for settlement. At this point, both UMHK and the colonial authorities made an error of judgment in grossly underestimating the future growth of the city. ${ }^{6}$ Profit was the main incentive, and the long-term consequences of a hurriedly built town were not considered.

Next, the hastily constructed labor camps, which were intended to be temporary, turned permanent. Indeed, in 1926, pushed by personnel shortages, UMHK launched a campaign to stabilize its workforce in order to, as the 
company's physician Léopold Mottoulle (1946:11) put it, "push the black worker to love his work and stick to it as long as possible." To make work in mining more attractive, the management endeavored to improve labor conditions, including supplying better accommodations, with dwellings in durable material which enabled the worker to settle with his wife and children (on the stabilization policy, see Rubbers 2013; Dibwe dia Mwembu 2001; De Meulder 1996; Banjikila Bakajika 1993; Perrings 1979; Fetter 1973). Note that the company created this homely atmosphere exclusively to safeguard human reproduction. Similar to what Kaveh Ehsani (2003:381) has suggested for company towns, labor camps, too, can be considered as "a second factory, built next to the main plant [...], for the production of the other essential component of the production process, namely labor power." The mining activities attracted a growing population, and the idea then arose that a town should be established nearby (Chapelier 1956a:299). Right from the start, it was clear that neoliberal thinking guided the process, with all interventions in the budding urban tissue aimed at keeping the company running. Correspondence shows that UMHK urged the colonial authorities to quickly choose the location of the future city so it could further develop its activities. ${ }^{8}$ Likewise, during all the following encounters with the authorities, all that UMHK did was to remind the state of the urgency of the situation, claiming that it wished to start construction without further ado. ${ }^{9}$

When, in 1926, a first draft of the future city was tabled, René Detroy, a Belgian urbanist, wrote a scathing criticism of the rush that had engulfed the project. In his words, "the draft of the project is not elaborated enough what concerns the allotments, the roadworks, the buildings, the esthetics and the order of urgency." The Belgian authorities in the metropolis, for their part, complained vociferously that their authority had been bypassed which they considered "dangereux." ${ }^{10}$ Nevertheless, UMHK won the day, and the Belgian authorities approved the rushed convention of 1930 concerning the creation of the agglomération urbaine de Musonoi, as it was then called. ${ }^{11}$ Just one year later, the Benguela Railway finally linked the three deposits to the port of Benguela on the Atlantic, and to the port of Lobito thirty-five $\mathrm{km}$ up farther north, and production hit the ground running. It increased even more steadily after 1937, when mechanized extraction took off (Perrings 1979:122) and the concentrator was installed (Henk 1988:156). Evidence suggests that Kolwezi then entered into a kind of competition with UMHK's other two centers of activity, Elisabethville and Panda-Likasi; to clear the backlog, UMHK ramped up production, and consequently, the area was urbanized with great speed. As UMHK attracted a growing number of European employees, administrators and retailers too moved in, together with other colonists. And as word spread that Kolwezi was the new hive of opportunity, African jobseekers came in droves, often clustering around the nearby village of Mwangeji. To channel this stream of so-called déracinés (the "uprooted" ones), the authorities planned a cité indigene, or indigenous neighborhood. ${ }^{12}$ But settling all these newcomers in a hurry had created a hodgepodge of neighborhoods and alleys. The idea then arose that it was 
time to streamline the budding city, since it clearly lacked coherence. Akin Mabogunje (1990:139) has shown that being scattered is not an unusual feature for a colonial city, but rather the result of "a fragmented civil society [which] ensures a selective approach to urban planning." Nevertheless, Kolwezi was fragmented to the extreme. The European administrators, the traders, the local workforce, and the immigrants were all accommodated in separate neighborhoods, with a neutral zone keeping the Africans out of the lives of the Europeans, and vice versa. In addition, the fair distance of fifteen kilometers between the three deposits, Ruwe, Kolwezi, and Musonoi, caused the city to be dispersed. UMHK had regrouped its labor camps and buildings around these three sites, and consequently, the town was scattered, too. "What strikes the visitor to this area is the eccentric location of its different centers of activity," was the verdict of Putmans, a visiting mining engineer, who added that without any doubt this was the result of the overhasty opening up of the mines of Groupe Ouest for exploitation. ${ }^{13}$

The consequences of the rapid industrialization and ensuing precipitous choice of location for the built areas-without decent plan or soil examinations-soon surfaced. As it turned out, buildings were erected on land that UMHK would have preferred to exploit. Already in 1940, nearly a year after the official birth of the urban agglomeration, the homes of two territorial agents in the Musonoi neighborhood needed to be destroyed since, as the company stated, they were situated "right on top of a mineral deposit." 14 The town's location became problematic as the mining industry gradually engulfed the town; it seemed to be hemmed in by open mines, plants, and a concentrator, but lacked an urban plan to straighten it all out (see Figure 2).

In 1947, the Belgian authorities sent architect-urbanist Noël Van Malleghem to the Belgian Congo to survey the area. He was particularly harsh regarding the messy ensemble that Kolwezi still presented, "by lack of a holistic plan." He outlined two major objections: the omnipresence of the

\section{Figure 2. Aerial view showing how the city of Kolwezi is completely surrounded by mining areas. Source: Google Maps.}

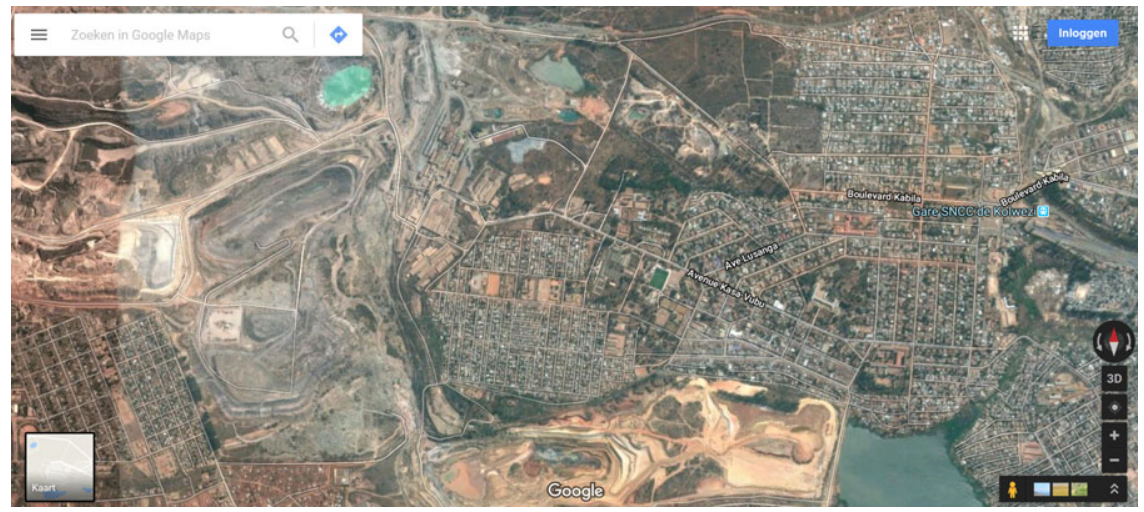


mining industry and the unfortunate location of the city. As he put it in his report, "we would like to stress how inconvenient it would be if Kolwezi were allowed to expand at its current location." 15 In his view, the hurried proceedings had led to band-aid solutions, and to a place where "houses are literally stuck to the industry." 16

The time had come to turn over a new leaf. Having hurriedly built to suit the greed of the company had not been a good idea. It is at this stage that for the very first time the idea arose to simply remove the city and relocate it elsewhere. With previously unexamined land and consequently undiscovered deposits all over, a resiting of the whole city seemed the only viable solution in the long run. Gilbert, a centenarian and inhabitant of the very first labor camp near the Kolwezi mine, now called cité Gécamines, remembers that the chef de cité regularly passed by the inhabitants to warn them that they should move, as their houses would be destroyed to make room for mining activities. ${ }^{17}$ Jeannette, who worked as a social assistant at UMHK, recalls that from the time she arrived in Kolwezi in 1957 onward, there were talks of the city's relocation. ${ }^{18}$ However, up until independence in 1960, the removal remained mere talk (see Figure 3).

It was not until 1972 that the (then Zairian) authorities undertook the first and only serious attempt to move the entire city, and the urbanists of the Bureau d'Études d'Aménagement Urbain (BEAU) developed the Schéma Directeur de Kolwezi II. At that time, the removal seemed to be certain, as

Figure 3. Aerial view of Kolwezi in 1956, showing that the city is adhered to by mining pits. Source: Frederic Berkmoes on www.inchi-yetu.be.

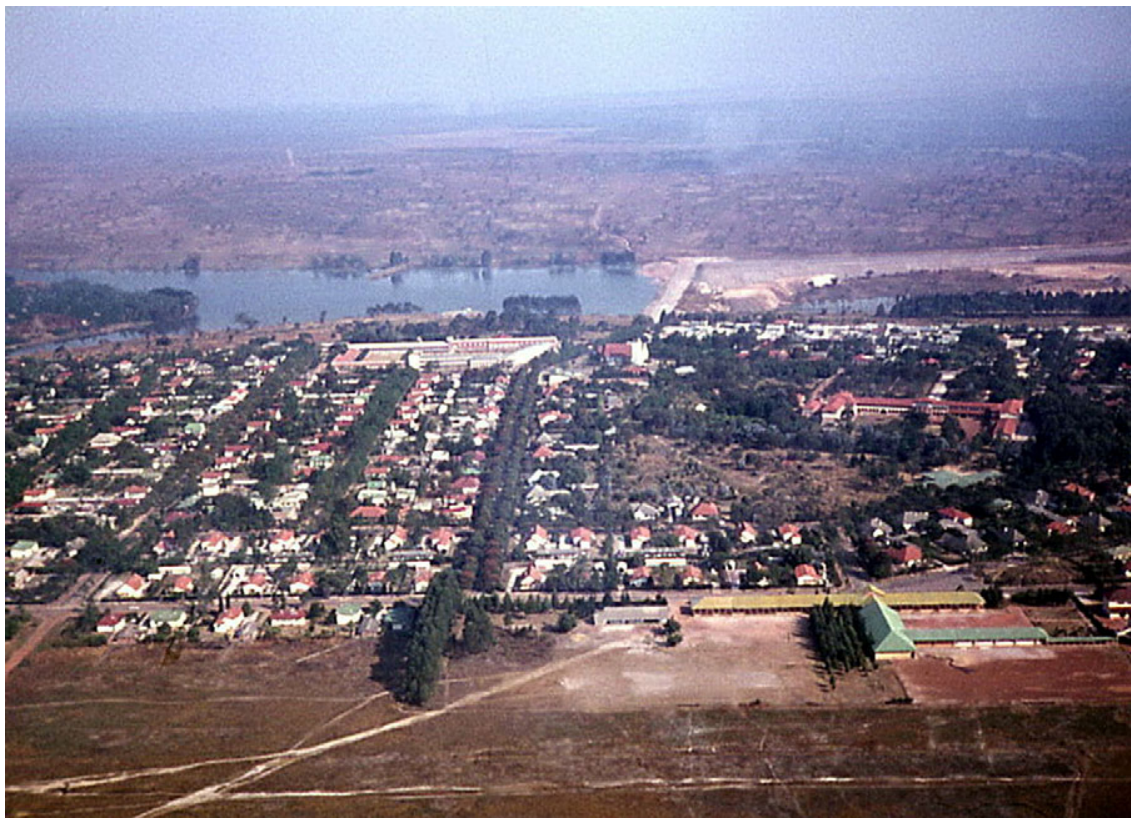


Gécamines was expanding - it had entered the boom period called $\mathrm{P} 2$-and so was the number of employees it had to accommodate, besides the extra migrants who were flocking into the newly built neighborhoods, attracted by the booming production. According to this plan, Kolwezi was to be relocated twenty kilometers eastward to the shores of Lake Nzilo, away from the industrial sphere to make it more city-like. After the removal, the existing city would be left to the company and entirely converted into an industrial area (Mansila Fu-Kiau 1988:278). The removal never actually transpired in any case, blocked by lack of funding (Bruneau \& Mansila Fu-Kiau 1986). ${ }^{19}$

In short, the precipitous planning of the city of Kolwezi, pushed by the capitalist logic of the major company that ruled the town, UMHK, resulted in its unfortunate location. The town is literally built upon rich deposits. And as mining rights always override land rights, the Kolwéziens had to get used to unexpected turns and to living on the edge of a removal to make room for mining activities. They have the feeling of being on borrowed time. And yet, as we will discuss next, they turned this predicament to their advantage.

\section{Local entrepreneurship on the margins of capitalism}

The lived experiences of the inhabitants of Kolwezi reveal how they deal with the unusual location of their city, planned fully at the service of the mining industry. Residents' worlding practices-a form of salvage accumulationallow them to integrate into capitalist circuits. Many simply started extracting ore from their own backyards. They were able to do so in the first place because many young male Kolwéziens had acquired artisanal digging skills throughout the years. Indeed, by the turn of the millennium, president Laurent-Désiré Kabila had legalized artisanal mining, albeit exclusively in concessions which either Gécamines or the governmental authorities had granted to the artisanal diggers (creuseurs). Gaining experience, these creuseurs also went on to mine illegally in the concessions of Gécamines or of private companies, further improving their skills (Cuvelier 2011). As a consequence, the number of creuseurs increased explosively. According to a 2008 World Bank report, creuseurs supply 90 percent of the total mineral production of the DRC (Cuvelier 2014). Note that more than half of the world's cobalt mine production comes from the Congolese Copperbelt (Banza Lubaba Nkulu et al. 2018). Many youngsters in Kolwezi, thus, are practiced at digging with bare hands and basic tools. Although these are not exactly labor conditions that conjure up economic efficiency in a capitalist context, through their salvage accumulation, Kolwezi's domestic diggers take part in the global supply chain, supplying the raw material which is high in demand and ultimately ends up in mobile phones, electric cars, and other capitalist commodities. As such, the inhabitants of Kolwezi capitalize on the unfortunate location of their city in order to take part in the neoliberal scheme that has a grip on it.

What happened in the Kasulo neighborhood is illustrative. In 2014, one of its inhabitants, an immigrant from the Kasai province, dug a hole in his 
modest rental home to serve as latrine pit. This was easy to do, as the floors of this neighborhood's dwellings consist of nothing but flattened earth. While digging, he found that his penurious plot had unexpected bonuses to offer: it appeared rich in cobalt ore. He started selling this material at the trading houses (comptoirs) at nearby Musompo where creuseurs-either legitimized ones or those working on illegal sites-sell their ore to traders, who are often Chinese. He soon gathered a small fortune, enabling him to move out and settle comfortably elsewhere. His stroke of luck inspired his neighbors, and they started digging in their compounds too. Before long, the whole Kasulo neighborhood had turned into a buzzy mining area. With their mallets and chisels, inhabitants dug as deep as forty meters to access the ore, tunneling underneath the whole neighborhood. Not everyone had the right skills to dig, though, and many residents allowed more experienced miners to dig in their compounds. The latter had taken up the trade along the way themselves.

To sink a shaft, however, remains a risky undertaking. As a rudimentary sketch drawn by a creuseur shows, the vertical shaft (cheminée) can be as deep as forty meters, and it has no lining; creuseurs dig out hand-and foot-grips in its sides to allow going up and down (see Figure 4). Once the vein of ore is reached, the vertical digging sets off. These vertical shafts (galéries) have no prop support or sprags, since the vein is hard enough in itself. Above ground, there is a generator and a motor (machine souffleur) feeding a tube that goes down with oxygen, as from eight meters below onward, the air gets very thin. Nevertheless, this does not prevent the creuseurs from smoking pot underground, in order to "be courageous," as one put it. "After all, it is your common sense (mayele) that will make sure accidents do not happen." ${ }^{20}$ In any event, it is a staggering endeavor. Usually, a team consisted of five creuseurs: 40 percent of the revenues went to the inhabitant who gave access to the compound, 40 percent to the five creuseurs, and 20 percent to their foreman. From each pit, between USD100 and USD200 worth of ore was extracted a day. The more experienced creuseurs deplored the competitive atmosphere on the site, with teams working independently instead of cooperating to improve the circulation of oxygen or offering mutual help when needed, as is usual on the sites of major mining companies. In all, a mixture of experienced and novice creuseurs jointly dug the backyards.

The first couple of years, the municipal and provincial authorities tried to curb these artisanal activities, but failing to provide the creuseurs with an alternative site, they chose to turn a blind eye. ${ }^{21}$ By the end of 2017, however, pushed by the findings of an Amnesty International report (2016) and fearing a negative image, they proclaimed manual digging in Kasulo illegal, falling back on the argument that the neighborhood was a residential area after all. Their main incentive, so they stated, was the poor labor conditions, endangering the lives of numerous children active on the site (Kayumba 2017). Moreover, some residents had not "rented" their compounds to diggers because they lacked the proper network or because they simply feared being penalized, as digging up ore is indeed prohibited. But these 
Figure 4. Sketch of a pit in the Kasulo neighborhood, drawn by a creuseur, July 30, 2018, in Kolwezi. Source: the author.

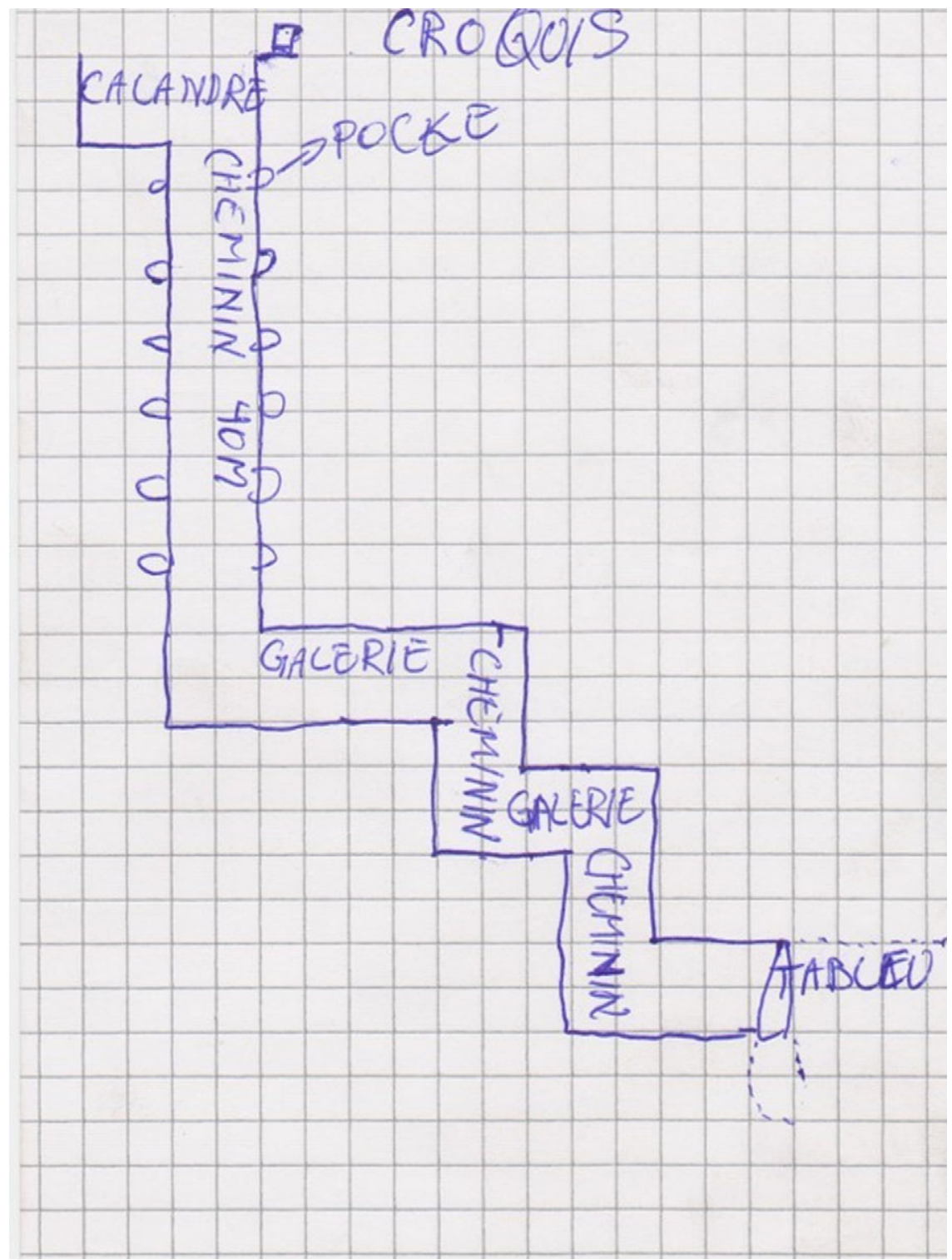

inhabitants continued to live in the neighborhood nevertheless, and without benefitting from the digging, they saw their lives endangered by the many shafts and tunneling that affected the stability of their houses.

The health implications of exposure to cobalt and toxic trace elements of uranium (Banza Lubaba Nkulu et al. 2018) are poorly appreciated. Although the authorities intervened, they were cautious not to antagonize the 
population by depriving them of their earnings and dwellings. The industrystate pact worked out a solution that had to prove some measure of corporate social responsibility. Gécamines, which still holds the Permit of Exploitation (PE) of this neighborhood, granted the concession to the Chinese company Congo Dongfang International Mining (CDM), and six hundred families were asked to move out, against payment. ${ }^{22} \mathrm{CDM}$ put a high wall around the neighborhood, and the Ministry of Mines turned its statute into a Zone for Artisanal Mining. CDM today engages some of the former inhabitants as well as about seven thousand creuseurs to continue to dig into, as one framed it, "his pit," but the miners need to sell all the extracted ore to the company exclusively. ${ }^{23}$ Being incorporated by the mining company thus means that their benefits decreased, as they receive less for the ore than they did at the trading houses in Musompo.

The story ends with an encouraging turn. By means of compensation, the authorities allotted a new neighborhood to the former residents of Kasulo. Interestingly, the decision makers once again made the very same mistake as during colonial times, acting in a hurry, with the mining industry again in the vanguard. The committee that decided where the inhabitants would be relocated did not include any expert on urbanism or geology. Rather, the Ministry of Mining held a prominent place, alongside employees of the cadastre. A member of the committee was flabbergasted by the way the new area was chosen, without any preliminary exploration of the soil, and without any regard for urbanist criteria. Instead, the employees of the cadastre pointed out a site that was vacant and the other committee members agreed that "this site looks nice." So when the inhabitants of Kasulo settled in their newly created neighborhood, Joli Parc in Samukinda, they were itching to start digging anew. They soon encountered yet another windfall: their new compounds too appeared to be rich in cobalt ore. It is too soon to tell whether the domestic diggers at Samukinda will also be overtaken by one of the multinationals that (temporarily) settle in their town, as was the case with the Kasulo diggers. But considering that Kolwezi is virtually constructed upon deposits, and a removal of the whole town is not on the current agenda, it is unlikely that these proceedings will end soon. It is important to note though, that the removal of entire neighborhoods affects above all the lower social classes. Indeed, the complete city is located upon deposits, but removing the fancier neighborhoods involves much higher indemnification costs.

In any event, the industry's appetite for valuable ores will only increase, now that electric cars are fast becoming a popular reality. Until alternatives are found, the lithium-ion batteries used by electric cars need cobalt. Bill Gates, Jeff Bezos, and a few other tycoons recently agreed to jointly hunt for undiscovered cobalt deposits, scouring the earth's crust and below in North America; other consortia are carrying out similar operations in Australia and Canada (Bloomberg 2019). In the meantime, the DRC provides more than two thirds of the global supply. Kolwezi offers a substantive amount already and could offer more, but this means that in the long run, more 
deposits need to be cleared of dwellings and other obstacles. Nevertheless, there is no guarantee that the population as a whole will profit from the increased demand for cobalt, despite the recent revision of the Mining Code which regulates the mining industry. Originally established in 2002 under the aegis of the World Bank, the code was revised in 2018, including an increase in the royalties and taxes that foreign mining companies need to pay, as well as the obligation to spend 0.3 percent of turn-over on social and environmental corporate responsibility measures. But whether this extra income will be well spent and improve the lives of the Congolese citizens, of course, depends largely on those who rule the country. Meanwhile, the capital drain to the foreign investors, which we discussed above, continues. The lack of a decent basic infrastructure-such as reliable provision of electricity-is keeping major profits for the communities out of reach too, since the refining phase, which realizes more profits than exporting unprocessed ore as happens today, is forcibly carried out abroad (Trefon 2016), in countries such as China, Finland, Canada, and Belgium (Banza Lubaba Nkulu et al. 2018).

\section{Futures of the wealth beneath}

By digging underneath their own houses, Kolwéziens simultaneously generate an income and undermine the very foundations of their homes. There is an absorbing observation to make at this site: the first inhabitant to discover minerals in his back yard did so while digging to create a septic tank. Indeed, many neighborhoods in Kolwezi lack a (decent) sewage system, although the inhabitants expect the authorities of their city, renowned for its mining industry and rich deposits, to provide one. But as we have seen, the relation between minerals and development is a precarious one; rich soils do not unavoidably lead to better lives. Even if it is true that the mining industry brought along job opportunities, unemployment is still rife. On top of this, there is a glass ceiling which prevents Congolese citizens from profiting to the full potential offered by such resources. The highest possible position for any Congolese in a foreign mining company is to be head of the human resources department, and this is only the case because the Congolese law requires it; all the other higher positions are exclusively filled by expatriates (Rubbers 2019).

In this imbalance, Kolwéziens are pushed to look for ways to claim their slice of the pie. This slice, however, might be thinner than it should be. Often, the diggers do not know the exact global market value of the ore they excavate. James Smith (2015) has shown that, to the artisanal miners in eastern Congo, capitalism is an abstract frame, but it is tied to a very concrete reality: the price they get at the comptoirs for the ore they delve. This price is disconnected from its "real" global market value, of which the miners are often unaware. Instead, they rely upon their personal networks of middlemen and traders, and through this network they try to control the price of the tin, tantalum, or tungsten they dig themselves. As such, this "real" price is socially 
constructed and not related to the more abstract free market ideology that rules the world.

Kolwezi residents are fully aware that the whole city is built upon rich mineral deposits; this is hardly a recent phenomenon. Without irony, Kolwéziens speak of "le gisement de l'hopital" in reference to the promising deposit on which the city's hospital is built. As one local geologist observed, "the hospital, the offices of Gécamines, the prison at Dilala and the entire neighborhood Kamina are constructed above deposits, this is just common knowledge." 24 The western part of the town is surrounded by a wasteland of disused mines and tailings, and scavenging Gécamines' tailings was a common and legitimate pastime. Kolwéziens sold the green malachite stones they found in the waste to an Indian artisan to make some extra money. The latter turned this material into ashtrays and jewelry to be marketed to the expatriates. Kolwéziens are not the only civilians to surreptitiously capitalize on the rich Congolese underground; residents of other cities of the former Katanga province do so as well. Since April 2018, inhabitants of the Kalipopo neighborhood in Likasi have also gone underground in their compounds to liberate precious mineral ore. Only four days after the first "discovery," entrepreneurs had sunk shafts in more than 150 compounds. ${ }^{25}$ Excavating one's own backyard has become a widespread notion in local imaginary, too, and it inspired Congolese writer Sinzo Aanza (2015) to dedicate a novel to Lubumbashi's domestic diggers. However marginal it may seem, such domestic practices cannot be overlooked.

The interfacing of the mining industry and urban planning is an uneasy process. As early as 1956, the urban geographer Alice Chapelier (1956b:50) observed that the harmonious development of Kolwezi was "compromised" by the occupation of a site which had been slavishly chosen for the sole function of the mining industry. In Kolwezi, in a very gradual way, the built space has encroached upon the mineral deposits because the city was built on the wrong spot. Today, mining activities are gnawing away at the city. Because of Kolwezi's unfortunate urban engineering, the city is gradually being eaten, not only by the mining industry, but also by the inhabitants, as the impromptu artisanal mining activities in the Kasulo neighborhood have shown (see Figure 5). As such, multiple scales and circuits of extraction co-exist in the city of Kolwezi.

But there were more than simply urbanistic flaws that led to an illpositioned city. Simply put, the soil is rich, but the people are poor. The benefits of the gifted soil slip away. There is an overpowering capitalist logic creeping above their heads, and it prevents communities as a whole from fully profiting from their land of plenty. Nevertheless, the Kolwéziens are resilient, and they find ways to sneak into the margins of the capitalist world order. By digging up precious ore from their own backyards, Kolwéziens claim a share of Congo's miraculously gifted soil. The domestic diggers simply cash in on the expensive dirt. 
Figure 5. Ruins of the houses in cité Gécamines that were abandoned to make room for the mining activities as the open pit in the background expanded. Source: the author.

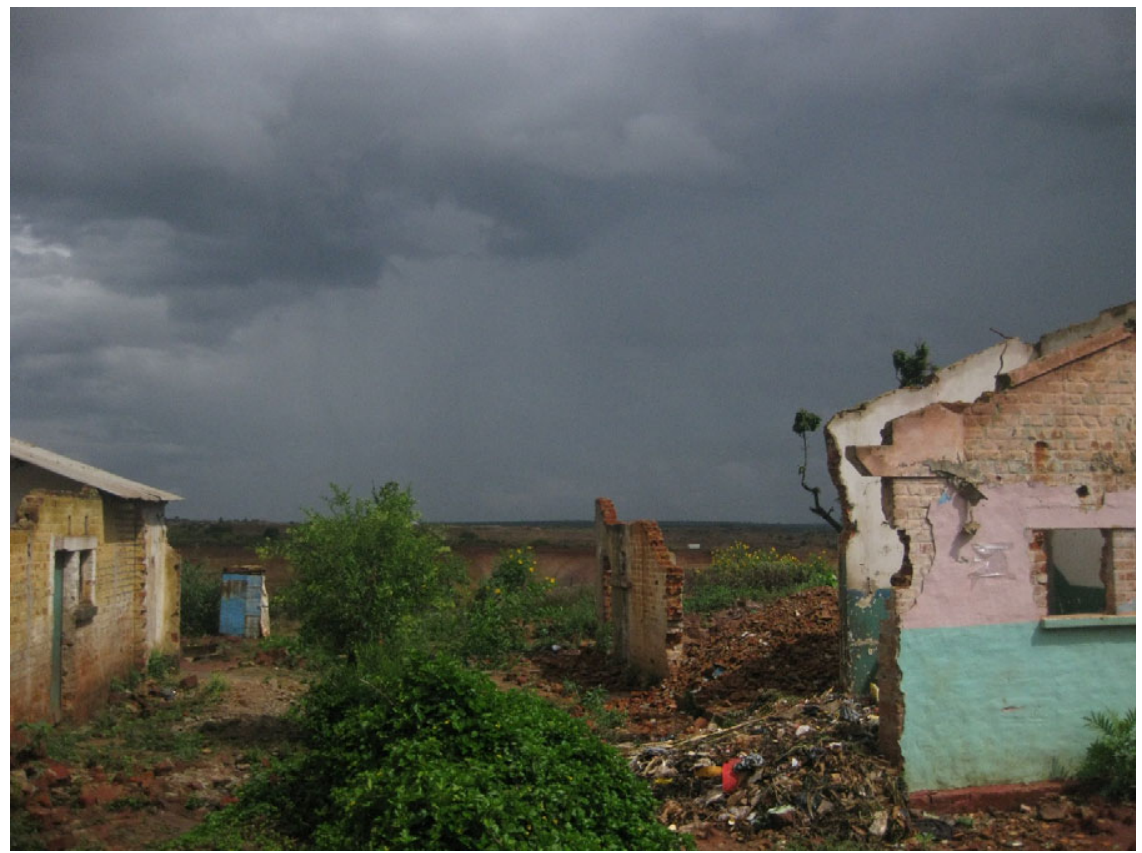

\section{Acknowledgments}

The author wishes to thank the reviewers for their insightful comments, and she is very grateful to Benjamin Lawrance for his generous and constructive support. This article was written as part of the WORKinMINING project (www.workinmining.ulg.ac.be). The project has received funding from the European Research Council (ERC) under the European Union's Horizon 2020 research and innovation programme (grant agreement no. 646802). The ideas developed in this article reflect only the author's view. The ERC is not responsible for any use that may be made of the information it contains.

\section{References}

Aanza, Sinzo. 2015. Généalogie d'une banalité. La Roque d'Anthéron: Vents d'ailleurs.

Amnesty International. 2016. This is what we die for. Human rights abuses in the Democratic Republic of the Congo power the global trade in cobalt. London: Amnesty International Ltd.

Ayimpam, Sylvie. 2019. “Kinshasa: Une Ville de la Débrouille?” In Kinshasa Chroniques/ Kinshasa Chronicles, edited by Dominique Malaquais, 280-87. Montreuil: Editions de l'Oeil. 
Banjikila Bakajika, Thomas. 1993. "Capitalisme, rapport salarial et regulation de la main-d'oeuvre: la classe ouvrière noire dans les camps de l'eUnion Minière du Haut-Katanga, 1925-1967.” Ph.D. diss., Université de Laval.

Banza Lubaba Nkulu, Célestin, Lidia Casas, Vincent Haufroid, Thierry De Putter, Nelly D. Saenen, Tony Kayembe-Kitenge, Paul Musa Obadia, Daniel Kyanika Wa Mukoma, Jean-Marie Lunda Ilunga, Tim S. Nawrot, Oscar Luboya Numbi, Erik Smolders and Benoit Nemery. 2018. "Sustainability of artisanal mining of cobalt in DR Congo." Nature Sustainability 1: 495-504.

Bloomberg. 2019. miningweekly.com/article/algorithms-join-hunt-for-cobaltbacked-by-gates-bezos-and-dalio-2019-03-04.

Bruneau, Jean-Claude, and Shourit Mansila Fu-Kiau. 1986. "Kolwezi: L'espace habité et ses problèmes dans le premier centre minier du Zaïre." Cahier des Sciences Humaines 22 (2): 217-29.

Bryceson, Deborah, and Danny MacKinnon. 2012. "Eureka and beyond: mining's impact on African urbanisation." Journal of Contemporary African Studies 30 (4): 513-37.

Büscher, Karen. 2018. "African cities and violent conflict: the urban dimension of conflict and post conflict dynamics in Central and Eastern Africa." Journal of Eastern African Studies 12 (2): 193-210.

Cassiman, Ann. 2019. "Spiders on the world wide web: Cyber trickery and gender fraud among youth in an Accra zongo." Social Anthropology 27 (3): 486-500.

Chapelier, Alice. 1956a. Elisabethville, Jadotville et Kolwezi. Etude de géographie urbaine comparée. Part one of Ph.D. diss., Université de Liège.

— 1956b. Elisabethville, Jadotville et Kolwezi. Etude de géographie urbaine comparée. Annexes. Part two of PhD. diss., Université de Liège.

Coquery-Vidrovitch, Catherine. 1988. "Villes colonials et histoire des Africains." Vingtième Siècle, revue d'histoire 20: 49-73.

Cuvelier, Jeroen, 2011. Men, mines and masculinities: the lives and practices of artisanal miners in Lwambo (Katanga province, DR Congo). Ph.D. diss., Ghent University.

- 2014. "Work and Masculinity in Katanga's Artisanal Mines." Africa Spectrum 49 (2): 3-26.

De Boeck, Filip, and Marie-Françoise Plissart. 2004. Kinshasa: Tales of the invisible city. Tervuren: Ludion.

De Hemptinne, Jean-Félix. 1926. "Les mangeurs de cuivre au Katanga.” Congol (3): 371-403.

De Meulder, Bruno. 1996. De kampen van Kongo: arbeid, kapitaal en rasveredeling in de koloniale planning. Amsterdam: Meulenhoff.

Dibwe dia Mwembu, Donatien. 2001. Bana Shaba abandonnés par leur père: Structures de l'authorité et histoire sociale de la famille ouvrière au Katanga 1910-1997. Paris: L'Harmattan.

Ehsani, Kaveh. 2003. "Social Engineering and the Contradictions of Modernization in Khuzestan's Company Towns: A Look at Abadan and Masjed-Soleyman.” International Review of Social History 48: 361-99.

Ferguson, James. 1999. Expectations of Modernity. Myths and Meanings of Urban Life on the Zambian Copperbelt. Berkeley: University of California Press.

Fetter, Bruce. 1973. L'Union Minière du Haut-Katanga, 1920-1940: Naissance d'une sousculture totalitaire. Les Cahiers du CEDAF 6.

Finn, Janet L. 1998. Tracing the Veins: Of Copper, Culture, and Community from Butte to Chuquicamata. Berkeley: University of California Press. 
Francaviglia, Richard V. 1991. Hard Places. Reading the landscape of America's historic mining districts. Iowa City: University of Iowa Press.

Gobbers, Erik. 2016. "Ethnic associations in Katanga province, the Democratic Republic of Congo: multi-tier system, shifting identities and the relativity of autochthony." Journal of Modern African Studies 54 (2): 211-36.

Gondola, Charles Didier. 1997. Villes miroir: Migrations et identités urbaines à Kinshasa et Brazzaville 1930-1970. Paris: L'Harmattan.

Graeber, David. 2018. Bullshit Jobs: A Theory. New York: Simon \& Schuster.

Hance, William A., and Irene S. van Dongen. 1956. "The Port of Lobito and the Benguela Railway." Geographical Review 46 (4): 460-87.

Henk, Daniel W. 1988. Kazi ya Shaba: Choice, Continuity, and Social Change in an Industrial Community of Southern Zaïre. Ph.D. diss., University of Florida.

Katzenellenbogen, Simon E. 1973. Railways and the copper mines of Katanga. Oxford: Clarendon Press.

Kayumba, Olivier. 2017. "Kasulo et Tshipuki fermeture des carriers pour le salut des enfants." Le Temps 7/2017: 4-6.

Kesselring, Rita. 2018. "At an extractive pace: Conflicting temporalities in a resettlement process in Solwezi, Zambia." The Extractive Industries and Society 5 (2): 237-44.

Lagae, Johan, Jacob Sabakinu Kivulu, and Luce Beeckmans. 2016. “'Pour Matadi la question (de la ségrégation) est encore plus grave qu'ailleurs': The making and shaping of a Congolese port city during the interwar years." Paper presented at conference The Belgian Congo between the two World Wars, Brussels, March 17-18.

Larmer, Miles. 2016. "At the Crossroads: Mining and Political Change on the Katangese-Zambian Copperbelt.” www.oxfordhandbooks.com/view/10.1093/ oxfordhb/9780199935369.001.0001/oxfordhb-9780199935369-e-20.

- 2017. "Permanent precarity: capital and labour in the Central African copperbelt." Labor History. https://www.tandfonline.com/doi/full/10.1080/ 0023656X.2017.1298712.

Lee, Ching Kwan. 2017. The Specter of Global China. Politics, Labor, and Foreign Investment in Africa. Chicago: University of Chicago Press.

Leech, Brian James. 2018. The City That Ate Itself: Butte, Montana and Its Expanding Berkeley Pit. Reno: University of Nevada Press.

Mabogunje, Akin L. 1990. "Urban Planning in the Post-Colonial State in Africa: A Research Overview." African Studies Review 33 (3): 121-203.

Mansila Fu-Kiau, Shourit. 1988. Kolwezi. L'émergence d'une grande ville minière au Zaïre méridonial. Ph.D. diss., Université de Lubumbashi.

Martinez-Fernandez, Cristina, and Chung-Tong Wu. 2009. Shrinking Cities: A Global Overview and Concerns about Australian Mining Cities Cases. Berkeley: University of California Press, IURD Monograph Series, Institute of Urban and Regional Development.

Martinez-Fernandez, Cristina, Ivonne Audirac, Sylvie Fol and Emmanuèle Cunningham-Sabot. 2012. "Shrinking Cities: Urban Challenges of Globalisation." International Journal of Urban and Regional Research 36 (2), 213-414.

Mottoulle, Léopold. 1946. Politique sociale de l'Union Minière du Haut-Katanga pour sa main d'oeuvre indigène et ses résultats au cours de vingt années d'application. Bruxelles: Institut Royal Colonial Belge.

Mukembe Mubedi, Marcellin. 2018. "Kolwezi : du peuplement primitif à la première moitié du XXième siècle (1700-1950)." Les Cahier du CRESA. Revue d'études économiques Ẽ sociales appliquées 51: 181-91. 
Ong, Aihwa. 2011. "Introduction. Worlding Cities, or the Art of Being Global." In Worlding Cities: Asian Experiments and the Art of Being Global, edited by Ananya Roy and Aihwa Ong, 1-26. Malden: Wiley-Blackwell.

Perrings, Charles. 1979. Black Mineworkers in Central Africa. Industrial strategies and the evolution of an African proletariat in the Copperbelt 1911-1914. London: Heinemann.

Pieterse, Edgar. 2010. "Cityness and African urban development." Working article/ World Institute Development Economics Research 42.

Piot, Charles, and Kodjo Nicolas Batema. 2019. The Fixer. Visa Lottery Chronicles. Durham: Duke University Press.

Robinson, Jennifer. 2002. "Global and World Cities: A View from off the Map." International Journal of Urban and Regional Research 26 (3): 531-54.

Rubbers, Benjamin. 2013. Le paternalisme en question. Les anciens ouvriers de la Gécamines face à la libéralisation du secteur minier katangais (RDCongo). Paris: L'Harmattan.

— 2019. "Mining Boom, Labour Market Segmentation and Social Inequality in the Congolese Copperbelt." Development and Change, http://hdl.handle.net/ $2268 / 238335$.

Särkkä, Timo. 2016. "The Lure of Katanga Copper: Tanganyika Concessions Limited and the Anatomy of Mining and Mine Exploration 1899-1906." South African Historical Journal 68 (3): 318-41.

Simone, AbdouMaliq. 2001. "On the worlding of African cities." African Studies Review 44 (2): 15-41.

Smith, James H. 2015. “'May it never end.' Price wars, networks, and temporality in the '3 Ts' mining trade of Eastern DR Congo." HAU: Journal of Ethnographic Theory 5 (1): $1-34$.

Trapido, Joe. 2015. “Africa's Leaky Giant.” New Left Review 92: 5-40.

Trefon, Theodore. 2004. "Introduction. La réinvention de l'ordre à Kinshasa." In Ordre et désordre à Kinshasa: Réponses populaires à la faillite de l'État, edited by Theodore Trefon, 13-31. Paris: L'Harmattan.

- 2016. Congo's environmental paradox: Potential and predation in a land of plenty. London: Zed Books.

Tsing, Anna. 2017 [2015]. The Mushroom at the End of the World. On the possibility of life in capitalist ruins. Princeton: Princeton University Press.

Udelsman Rodrigues, Cristina, and Ana Paula Tavares. 2012. "Angola's planned and unplanned urban growth: Diamond mining towns in the Lunda Provinces." Journal of Contemporary African Studies 30 (4): 687-703.

Vandemoortel, Bram. 2014. Embodied extraction. Spatial narrations on West Village as South African mining town. Master's diss., University of Ghent.

Van Doorninck, Nicolaas Hendricus. 1928. De Lufilische plooiing in den Boven Katanga (Belgischen Congo) naar eigen waarnemingen en naar critisch overzicht van de er over verschenen publicaties. Gravenhage: G. Naeff.

Vwakyanakazi, Mukohya. 1988. "Small Urban Centers and Social Change in SouthEastern Zaïre.” African Studies Review 31 (3): 85-94.

\section{Notes}

1. Gilbert, interview by the author, Kolwezi, June 27, 2018. All the names of the interviewees have been changed.

2. Katanga is the former name of the province that included the three main towns and centers of activity of UMHK: Elisabethville (now Lubumbashi), Jadotville 
(now Likasi) and Kolwezi. Since 2015, when the eleven provinces were cut up into twenty-six provinces, Katanga has been divided into four provinces. Kolwezi is the capital of the Lualaba province.

3. A brief discussion of toponyms is warranted here. Before Kolwezi was urbanized, there were three deposits nearby, called Ruwe, Musonoi, and Kolwez. The name Kolwezi was not used to refer to the urban area until December 1939, when the colonial authorities accorded the place the statute of circonscription urbaine, before that, the name Kolwezi referred to the river and the deposit exclusively. To refer to the place, different names were in use at the same time, often related to one of the other two deposits, Ruwe or Musonoi. At some stage, Jadotville was in the running too, but in 1930 this name was accorded to the city created close to UMHK's production centre Panda (currently Likasi) (Henk 1988:155; Chapelier 1956a:300).

4. African Archives Brussels (henceforth AA) AGR2/1269: "Gisement AuroPlatinifère de Ruwe. Résumé de la documentation existente par E M Richet."

5. AA AGR2/1269: "Gisement Auro-Platinifère de Ruwe. Résumé de la documentation existente par E M Richet."

6. AA T(114), 371: “Convention entre le Comité Spécial du Katanga et l’Union Minière du Haut-Katanga pour l'établissement d'une agglomeration urbaine dans la region des mines de l'Ouest." August 11, 1930; AA 3DG(1750) 10: "Rapport d'inspection des mines de la région de Musonoie" by E. Putmans, December 1938.

7. All translations by the author.

8. AA 3DG(824)3: letter from head of UMHK to head of CSK, June 12, 1929.

9. AA 3DG(824)3: report of the meeting on June 26, 1929.

10. AA 3DG(824)3 : letter by Ministère des Colonies to secrétaire générale of CSK, February 12, 1930.

11. AA T(114), 371: "Convention entre le Comité Spécial du Katanga et l'Union Minière du Haut-Katanga pour l'établissement d'une agglomeration urbaine dans la region des mines de l'Ouest." August 11, 1930.

12. AA Rapport AIMO 1946 by L. Henroteaux, administrateur territorial principal, January 29, 1947. By 1946 the cité indigène was finished, and about twelve hundred inhabitants had settled there.

13. AA 3DG(1750)10: "Rapport d'inspection de la mine de cuivre de l'UMHK à Musonoie" by E. Putmans, July 6, 1936.

14. AA 3DG(138) 4: report of meeting in Brussels between colonial authorities, CSK, UMHK and Cofoka, April 17, 1940.

15. AA 3DG(186) 1: "Avant projet du plan général d'aménagement” by Van Malleghem, 1947.

16. AA 3DG(200) 1: "Rapport de mission" by Van Malleghem, 1949.

17. Gilbert, interview by the author, Kolwezi, November 22, 2017.

18. Jeannette, interview by the author, Kolwezi, March 30, 2017.

19. The International Bank for Reconstruction and Development was supposed to fund the removal (Mansila Fu-Kiau 1988:79).

20. Kape, interview by the author, Kolwezi, June 30, 2018.

21. www.radiookapi.net/actualite/2014/07/24/kolwezi-les-creuseurs-artisanauxsommes-darreter-lexploitation-miniere-kasulo.

22. CDM is a 100 percent owned subsidiary of China-based Zhejiang Huayou Cobalt Company Ltd, one of the world's largest manufacturers of cobalt products. It is Gécamines, DR Congo's major state-owned mining company, that holds the 
permits d'exploitation (PEs) for the deposits situated in the former Katanga province. Since 2003, Gécamines establishes partnerships with foreign mining companies to which it grants concessions and PEs. Usually it holds a 32 percent share.

23. Dieumerci, interview by the author, Kolwezi, January 28, 2018.

24. Laurent, interview by the author, Kolwezi, June 25, 2018.

25. http://www.radiookapi.net/2018/04/05/actualite/societe/rdc-le-cobaltcreuse-dans-des-parcelles-residentielles-de-likasi. 